\title{
Baseline Survey for \\ Astragalus barrii Barneby (Barr's Milkvetch) and Physaria didymocarpa var. lanata A. Nels (Woolly Twinpod) in Eastern Big Horn and Southwestern Rosebud Counties, Montana
}

Prepared for:

The Bureau of Land Management

\section{Prepared by:}

Amy Taylor and Richard Caners

Montana Natural Heritage Program Natural Resource Information System Montana State Library

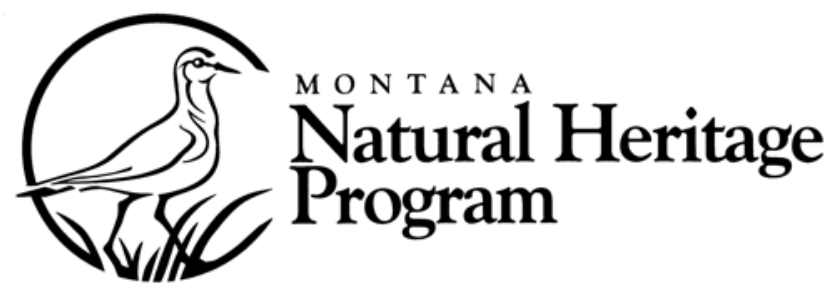




\title{
Baseline Survey for Astragalus barrii Barneby (Barrís Milkvetch) and Physaria didymocarpa var. lanata A. Nels (Woolly Twinpod) in Eastern Big Horn and Southwestern Rosebud Counties, Montana
}

\author{
Prepared for : \\ Bureau of Land Management \\ Miles City Field Office \\ 111 Garryowen Rd. Miles City, MT 59301 \\ Agreement \# ESA010009 Task \# 5 \\ Prepared by: \\ Amy Taylor, Contract Botanist and \\ Richard Caner, Botany Program Manager

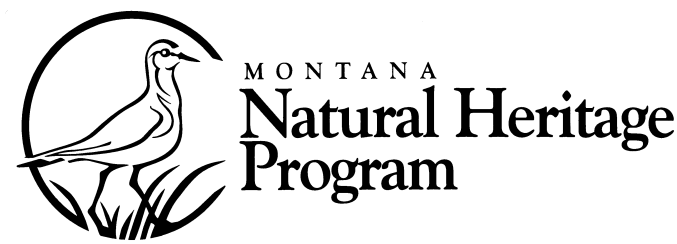

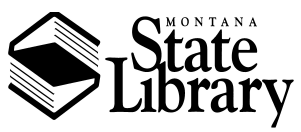

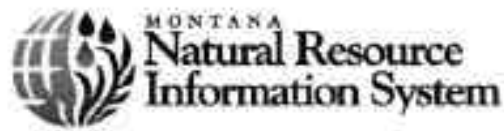

(C) 2001 Montana Natural Heritage Program

P.O. Box $201800 \bullet 1515$ East Sixth Ave • Helena, MT 59620-1800 • 406-444-3009

This document should be cited as follows:

Taylor, A and R. Caners. Baseline Survey for Astragalus barrii Barneby (Barrís Milkvetch) and Physaria didymocarpa var. lanata A. Nels. (Woolly Twinpod) In Eastern Big Horn and Southwestern Rosebud Counties, Montana. 


\section{Acknowledgements}

Many thanks to all the individuals who contributed to this project. A special thanks to Louise de Montigny, Bureau of Land Management, Miles City Field Office, for the provision of logistical support, and to Kent Undlin, Dawn Doran and Jeff Gustad from the field office for their accompaniment in the field. Thanks to Ron Hartman for use of the Rocky Mountain Herbarium for specimen identification, Spring Creek Coal for access to known locations of sensitive plants, and to all landowners who provided access to conduct surveys. Richard Caners, Botany Program Manager, Montana Natural Heritage Program, edited and prepared this document for submission. 


\section{Table of Contents}

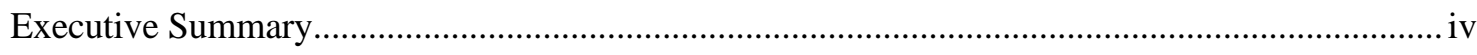

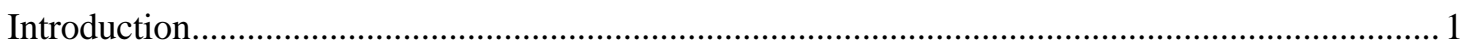

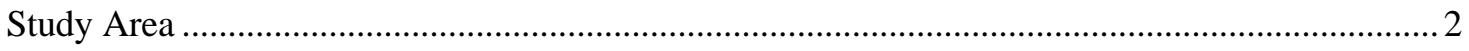

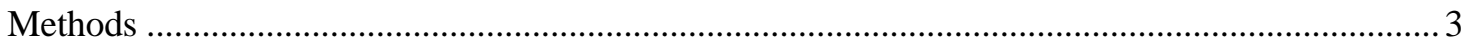

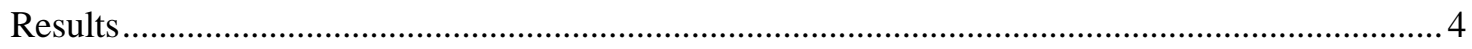

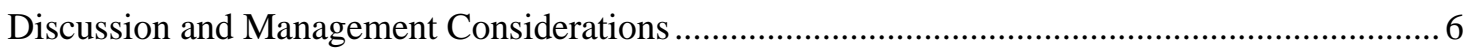

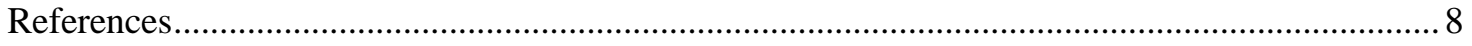

\section{Figures and Tables}

Figure 1. Localities of Astragalus barrii within study area................................................... 9

Figure 2. Localities of Physaria didymocarpa var. lanata within study area .............................. 10

Table 1. Occurrence records for Astragalus barrii in the project study area ............................ 11

Table 2. Occurrence records for Physaria didymocarpa var. lanata in the project

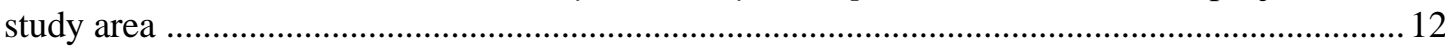

\section{Appendices}

Appendix 1. Pertinent biological information for Astragalus barrii and Physaria

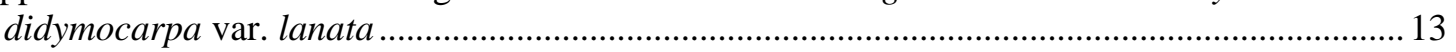

Appendix 2. Potential and existing habitat for Astragalus barrii and Physaria

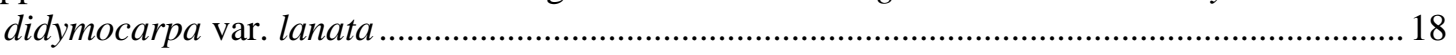

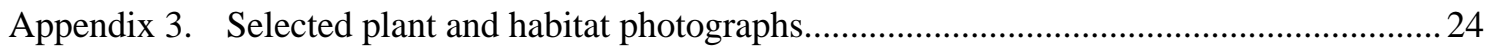




\section{Executive Summary}

In 2001, The Bureau of Land Management (BLM) Miles City Field Office contracted with the Montana Natural Heritage Program (MTNHP) to conduct baseline surveys for two species of Special Concern, Astragalus barrii Barneby (Barr's milkvetch) and Physaria didymocarpa var. lanata A. Nels. (woolly twinpod), in eastern Big Horn County and southwestern Rosebud County. Both of these species are regional endemics, their overall range being restricted to portions of adjacent Montana, Wyoming and South Dakota.

Both species are known to occur within the study area, but had not been systematically inventoried. Prior to this survey, $P$. didymocarpa var. lanata was known in Montana from only one location in Big Horn County, and had been documented from 14 occurrences in north-central Wyoming. A. barrii had previously been documented from 33 locations in southeastern Montana, and was known from South Dakota and Wyoming.

Surveys from this study resulted in four new occurrences of $P$. didymocarpa var. lanata and one new occurrence of $A$. barrii in the study area. Habitat information including associated plant species, and topographic and edaphic conditions was collected. This information provides additional baseline information for both species in Montana, and serves as a basis for BLM evaluation of the potential impacts of coal bed methane development on these plants and their habitats. The information found in this report may also help clarify the BLM status of these species, and will assist BLM staff with future field identification of both species and their respective habitats. 


\section{Introduction}

In 2001, The Bureau of Land Management (BLM) Miles City Field Office contracted with the Montana Natural Heritage Program (MTNHP) to conduct baseline surveys for two species of Special Concern, Astragalus barrii Barneby (Barr's milkvetch) and Physaria didymocarpa var. lanata A. Nels. (woolly twinpod), in eastern Big Horn County and southwestern Rosebud County. Both of these species are regional endemics, their overall range being restricted to portions of adjacent Montana, Wyoming and South Dakota. A. barrii is presently ranked at the global and state levels as G3 S3, suggesting the plant is vulnerable because of rarity or restricted range, even though it may be abundant at some of its locations (Heidel 2001). P. didymocarpa var. lanata is presently ranked as G5T2 S1, suggesting the plant is critically imperiled at the state level because of extreme rarity and/or other factors making it highly vulnerable to extinction (Heidel 2001).

The purpose of this study was to identify additional areas of occurrence or potential occurrence, and in the process develop a better understanding of the habitat characteristics of these species. Surveys were focused on BLM lands in eastern Big Horn and Rosebud Counties to provide additional information on species' distribution and habitat requirements, to document factors that have the potential to affect the long-term viability of the species in the area, and to provide management recommendations for the species based on new and existing information.

Both $A$. barrii and $P$. didymocarpa var. lanata are known to occur within the study area, but had not been systematically inventoried. Prior to this survey, $P$. didymocarpa var. lanata was known in Montana from only one location in Big Horn County. This species is also documented from 14 occurrences in north-central Wyoming. A. barrii is also known from South Dakota and Wyoming, and had previously been documented from 33 locations in southeastern Montana. This species is maintained as a Watch species on the BLM Montana State Plant List (BLM 1996).

Pertinent biological information for both species is outlined in Appendix 1. This information provides a more in-depth understanding of the species' habitat and conservation needs. 


\section{Study Area}

The study area is defined as eastern Big Horn County and southwestern Rosebud County, Montana, bounded by the Crow Reservation (west), Cheyenne Reservation (north), Custer National Forest (east) and Wyoming border (south) (see Figures 1 and 2, study area extent). The Tongue River and its drainages characterize the central portion of the study area. Geologically, examples of the Tertiary Fort Union Formation are found throughout the area. The formation consists of alternating layers of shale, clay siltstone and sandstone, and contains many clinker (also known as red scoria: baked sandstone and shale) and coal beds. The upper part of the Fort Union Formation is the Tongue River Member, which is the most productive coal-bearing geologic section in Montana (Soil Survey 1996).

Tracts of land managed by the BLM or the State of Montana are interspersed among large areas of private land, with livestock grazing as the dominant agricultural industry. Coal mining operations are currently localized in the southwestern part of Big Horn County within the survey area.

Ponderosa pine woodland, grassland, sagebrush steppe and barren calcareous substrate are found throughout the study area. The habitat of $A$. barrii is characterized by a very sparse cover of Pinus ponderosa (ponderosa pine) or Juniperus scopulorum (Rocky Mountain juniper) at some locations, but often only a sparse shrub cover of Artemisia tridentata (big sagebrush) and/or Atriplex confertifolia (shadscale) is present. Vegetative cover of grasses and forbs at these sites is low, with few dominant species (Heidel \& Marriott 1996). In southeastern Montana, the dominant plant species associated with A. barrii include Pascopyrum smithii and Elymus lanceolatus (western and thickspike wheatgrass, respectively), Stipa viridula (green needlegrass), Andropogon scoparius (little bluestem), Agropyron spicatum (bluebunch wheatgrass), Koeleria macrantha (prairie junegrass), native legumes, Artemisia tridentata (big sagebrush), Atriplex gardneri (Nuttall saltbush) and Krascheninnikovia lanata (winterfat) (Heidel \& Marriott 1996).

Much less information is available on the habitat and species associated with $P$. didymocarpa var. lanata, although occurrence records for the species in the Heritage database suggest that habitat characteristics and species associations are somewhat similar to that of A. barrii. Commonly associated species include Pinus ponderosa, Juniperus scopulourm, Rhus trilobata (fragrant sumac), Artemesia spp., and the graminoids Agropyron spicatum and Stipa comata (needle-and-thread grass). 


\section{Methods}

Prior to beginning fieldwork, we identified potential habitat for Astragalus barrii and Physaria didymocarpa var. lanata using USGS topographic maps, soil data (Soil Survey 1996) and information collated from the MTNHP database. Although an optimal start date for field work would have been in late May - early June, corresponding with the flowering times of both species, the earliest start time for this project had to be scheduled for mid-June. To verify that A. barrii and P. didymocarpa var. lanata plants had the reproductive or vegetative structures needed for positive identification, we initially surveyed some known locations for each species. Populations of both species were visited near Spring Creek Mine on June 18, 2001. Specimens of $P$. didymocarpa var. lanata had mature fruit. The most diagnostic characteristic for this taxon is the long, tangled spreading hairs on the leaves. Although leaf pubescence is sufficient for identification (Fertig 2000), fruit characters contribute to the positive identification of the species. Flowers or their remnants are necessary to positively identify A. barrii from other area Astragalus species that have compound leaves with three leaflets and cushion-forming habit (Heidel \& Marriott 1996). The timing of the surveys fell at the end of $A$. barrii's blooming period and after an unusually dry May. Therefore, visits to known locations were warranted to determine phenology. Individuals of this species found at the Spring Creek location had faded remnant flowers and mature fruit. A suite of characters including petal size, calyx size, peduncle length and leaflet morphology were sufficient to identify the plants as A. barrii.

Surveys were expanded to areas of potential habitat once we confirmed that diagnostic characteristics could still be observed in the field.

We contracted with Amy Taylor, a consulting botanist who has field experience identifying A. barrii in nearby portions of Wyoming, to conduct field surveys between June 18-27, 2001. Priority was given to potential habitats on the largest tracts of BLM-administered lands in the study area. Surveys were also conducted on state lands and, where permission was granted, on private lands.

For each species, we developed a search profile for potential habitat, based on existing habitat information:

A. barrii: Ridgetops, buttes, outcrops, badlands and slopes with sandy clay loam soils or calcareous substrates; vegetation associations of sagebrush-grassland, ponderosa pine and Rocky Mountain juniper, or cushion communities; typically sparsely vegetated areas.

P. didymocarpa var. lanata: Slopes and road cuts with red scoria (clinker) and clayshale substrates; also calcareous substrates and gravelly unstable slopes; emphasis on south-facing slopes; sparsely vegetated areas in sagebrushgrassland, mixed-shrub, and ponderosa pine communities; near 3800 f.a.s.l. and above.

For each population of $A$. barrii or $P$. didymocarpa var. lanata that was visited in the field, we completed an MTNHP Plant Species of Concern Survey form, including documentation of Ecological Rangeland Sites (Natural Resources Conservation Service 2000). Global Positioning System coordinates were taken for new locations of the target species. Where appropriate, slide and print photographs were taken and subsequently entered into the MTNHP's Slide Image Database (SID). Voucher specimens were collected and verified at the Rocky Mountain Herbarium in Laramie, Wyoming. Landowner permissions were also documented. 


\section{Results}

All new and existing occurrences of Astragalus barri and Physaria didymocarpa var. lanata in the study area are mapped in Figures 1 and 2, respectively, and described in Tables 1 and 2, respectively. Occurrence numbers associated with specimens in Figures 1 and 2 correspond with occurrence numbers in Tables 1 and 2, and are the numbers assigned to the occurrences in the Heritage database. No other Species of Concern were encountered during the survey. Search routes for both species are indicated on the 1:24,000 USGS Quad maps found in Appendix 2. The search routes define both areas of potential habitat that were identified and surveyed (solid black lines), as well as potential habitat that was identified in the field but not surveyed (solid red lines). Selected photographs from the project are included in Appendix 3.

Population sizes of $A$. barrii in the study area vary widely, ranging from less than 10 to thousands of individuals (see Table 1). The one new population documented in the study area consists of 4 major clusters of individuals approximately $12 \mathrm{~cm}$ wide. Population sizes of $P$. didymocarpa var. lanata in the study area (including the 4 new occurrences) range in size from 16 to thousands of individuals (Table 2).

The habitat information for the one new occurrence of $A$. barrii in the study area is consistent with other records in the study area for the species (see Table 2). The species typically occurs on red shale and sandstone outcrops with the associated species Juniperus scopulorum (Rocky Mountain juniper), Pinus ponderosa (ponderosa pine), Agropyron spicatum (bluebunch wheatgrass) and Artemisia tridentata (big sagebrush).

Habitat information for $P$. didymocarpa var. lanata in the study area has been greatly improved upon with the discovery of four new occurrences. Habitat summaries are provided in Table 2. Generally, the species occurs on steep, south- to southwest-facing slopes of sandstone outcrops and red shale, with the associated species Pinus ponderosa, Juniperus scopulorum, Agropyron spicatum and Rhus trilobata (fragrant sumac). The habitat characteristics and associated species of $P$. didymocarpa var. lanata appear to be relatively similar to that of $A$. barrii.

New occurrence records for $A$. barrii and $P$. didymocarpa var. lanata were found along 5 of the approximately 17 search routes (delineated with solid black lines; Appendix 2). Potential unsurveyed habitat for both species has been illustrated with solid red lines. This habitat has the potential to support new populations of both species and should be more carefully examined.

\section{Ecological Site Associations}

Both species occur in the Major Land Resource Area 58AE, the Eastern Sedimentary Plains (USDA 2000). The one new occurrence of A. barrii was found on the Badlands (BL) Rangeland Ecological Site, while the four new occurrences of $P$. didymocarpa var. lanata were found on Coarse Clay (CC), Badlands (BL) and Thin Breaks (TB) Rangeland Ecological Sites. Badlands (BL) and Thin Breaks (TB) Rangeland Ecological Sites belong to Group 4 of the Montana Key for Ecological Sites (USDA 2000), keying out as sites that are treated as complexes. Coarse Clay (CC) Rangeland Ecological Sites belong to Group 2, keying out as sites that are affected by reduced moisture, generally due to a lack of soil depth, salts or slope (USDA 2000). 
Thin Breaks (TB) Rangeland Ecological Sites are characterized by a landscape that has steep to very steep, angular and rough topography, with the tops of these sites appearing somewhat level. Outcrops of sandstone, silt-stone or other hard rock dominate parts of the site. There are numerous ledges where an occasional tree occurs. The majority of vegetation is generally typical of sandy or silty sites, but with more shrubs (USDA 2000).

Badlands (BL) Rangeland Ecological Sites are characterized by landscapes which are more rounded, with the tops of hills and knobs appearing more rounded, and have outcrops of shales as a dominant part of the landscape. There is often evidence of salts, often occurring around the base of hills and knobs. Very few trees occupy this site, with an occasional Juniperus scopulorum. Vegetation is sparse. The species present are often typical of clayey sites, but with a greater abundance of shrubs (USDA 2000).

Coarse Clay (CC) Rangeland Ecological Sites occur on undulating to rolling uplands, fans, foot slopes and low ridges. A coarse clay site is normally located on unstable landscapes of slumping shales, commonly with hummocky or dune-like topography. These sites have soils with less than 10 inches to hard bedrock (USDA 2000). 


\section{Discussion}

This survey generated valuable new information on the habitat requirements and geographic distribution of Astragalus barrii and Physaria didymocarpa var. lanata in eastern Big Horn and southwestern Rosebud Counties. Prior to the surveys, P. didymocarpa var. lanata was known in Montana from only one location in Big Horn County. Occurrences are now documented from one more location in Big Horn County and three locations in Rosebud County. One new small population of A. barrii was observed and documented in Rosebud County.

Few studies have addressed the direct impacts and threats affecting the long-term viability of the species. Heidel \& Marriott (1996) indicate that A. barrii is found on secondary range, and is characterized by a low, tufted growth form and early-season flowering. The species is therefore minimally affected by grazing management, unless livestock developments are placed near populations or grazing fosters weed encroachment or major shifts in plant community development that otherwise increase competition. Both Melilotus officinalis (yellow sweetclover) and the native species Triodanis perfoliata (Venus looking glass) have been observed to dominate some areas, apparently corresponding with heavy grazing in directly adjoining habitat. The same authors also suggest that the species may be affected by herbicide spraying and early-season pesticide spraying (Heidel \& Marriott 1996).

Coal bed methane development has the potential to alter and degrade habitat of A. barrii and $P$. didymocarpa var. lanata (Schassberger 1990; Heidel \& Marriott 1996; Taylor pers. obs.). Known locations of both species exist near coal mines or in areas of proposed development. Shale, clay siltstone, sandstone and red clinker characterize much of the study area and support habitat where both species are known to occur. Grazing, quarrying and exotic species are potential low-level threats that may also exist (Schassberger 1990; Heidel \& Marriott 1996). Large-scale modification of habitat as a result of extensive physical removal and damage are activities that have the potential to negatively affect the long-term viability of both species.

Recommendations for maintaining viable populations of $A$. barrii and $P$. didymocarpa var. lanata include (adapted from Heidel and Marriot 1996):

\section{A. Protection of natural habitats on BLM administered lands that currently support populations}

Protection may be achieved by recognizing the sites with stable populations as special management areas. The Zook Creek populations of $P$. didymocarpa var. lanata may receive protection since they lie within a BLM Wilderness Study Area. Management priority should be given to both species, with consideration being given to $P$. didymocarpa var. lanata as an addition to the BLM's Sensitive or Watch list.

Heidel and Marriott (1996) recommend the protection of natural habitats that support large populations of $A$. barrii, as larger populations appear to be buffered against drought conditions.

\section{B. Regulation of activities directly adjoining native habitats that support populations}

Thorough population surveys and assessments should be conducted prior to proposed disturbances within or near any documented populations of $A$. barrii and P. didymocarpa var. lanata and their potential habitats. These species should be addressed in management decisions regarding grazing allotments, weed management plans, oil and gas leases, mining permits and similarly-related activities. 


\section{$\underline{\text { Recommendations for further assessment }}$}

Due to the prevalence of potential habitat for A. barrii and $P$. didymocarpa var. lanata in the study area, there is a high likelihood that additional populations remain undiscovered (Schassberger 1990; Taylor pers. obs.). Some areas, identified as potential habitat, were not surveyed due to time constraints or access limitations (see Appendix 2). BLM-Miles City Field Office staff who conduct fieldwork within the study area are encouraged to become familiar with field recognition of $A$. barrii and $P$. didymocarpa var. lanata, as well as their habitats and closely-related species. The new occurrence of $A$. barrii near Whitten Creek is comprised of just a few individuals. Further searches within the State section and adjacent BLM sections are warranted in order to obtain a more accurate population size. A. barrii should be surveyed from early to mid-May when it is typically in full bloom. Dried remnant flowers often loose their color making the species more difficult to confidently identify. 


\section{References}

Bureau of Land Management (BLM). 1996. Special Status Species Plant Policy. Montana State Office, Department of the Interior. 49 pages.

Dorn, R. D. 1992. Vascular Plants of Wyoming, Second Edition. Mountain West Publishing, Cheyenne, Wyoming. 340 pages

Fertig, W. 2000. State Species Abstract: Physaria didymocarpa var. lanata. Wyoming Natural Diversity Database, Laramie, Wyoming. 2 pages

Heidel, B. L. and H. Marriott. 1996. Sensitive plant species survey of the Ashland District, Custer National Forest, Powder River and Rosebud Counties, Montana. Unpublished report to the Custer National Forest. Montana Natural Heritage Program, Helena. 94 pages plus appendices.

Heidel, B. L. and J. Vanderhorst. 1999. Sensitive plant species surveys: Butte district, Beaverhead and Madison Counties, Montana. Report to the Bureau of Land Management, Billings. 85 pages plus appendices.

Schassberger, L. A. 1990. Report on the conservation status of Astragalus barrii, a candidate threatened species. Unpublished report to the U.S. Fish \& Wildlife Service, Denver. Montana Natural Heritage Program, Helena, Montana. 85 pages

Soil Survey of Rosebud County Area and Part of Big Horn County, Montana: Part I and Part II. 1996. United States Department of Agriculture, Natural Resources Conservation Service. In cooperation with Montana Agricultural Experiment Station.

United States Department of Agriculture (USDA), Natural Resources Conservation Service (NRCS). 2000. Montana Key for Ecological Sites. Unpublished Draft (10/2000) on file at the Montana Natural Heritage Program. 7 pages. 


\section{As tragalus barrii}

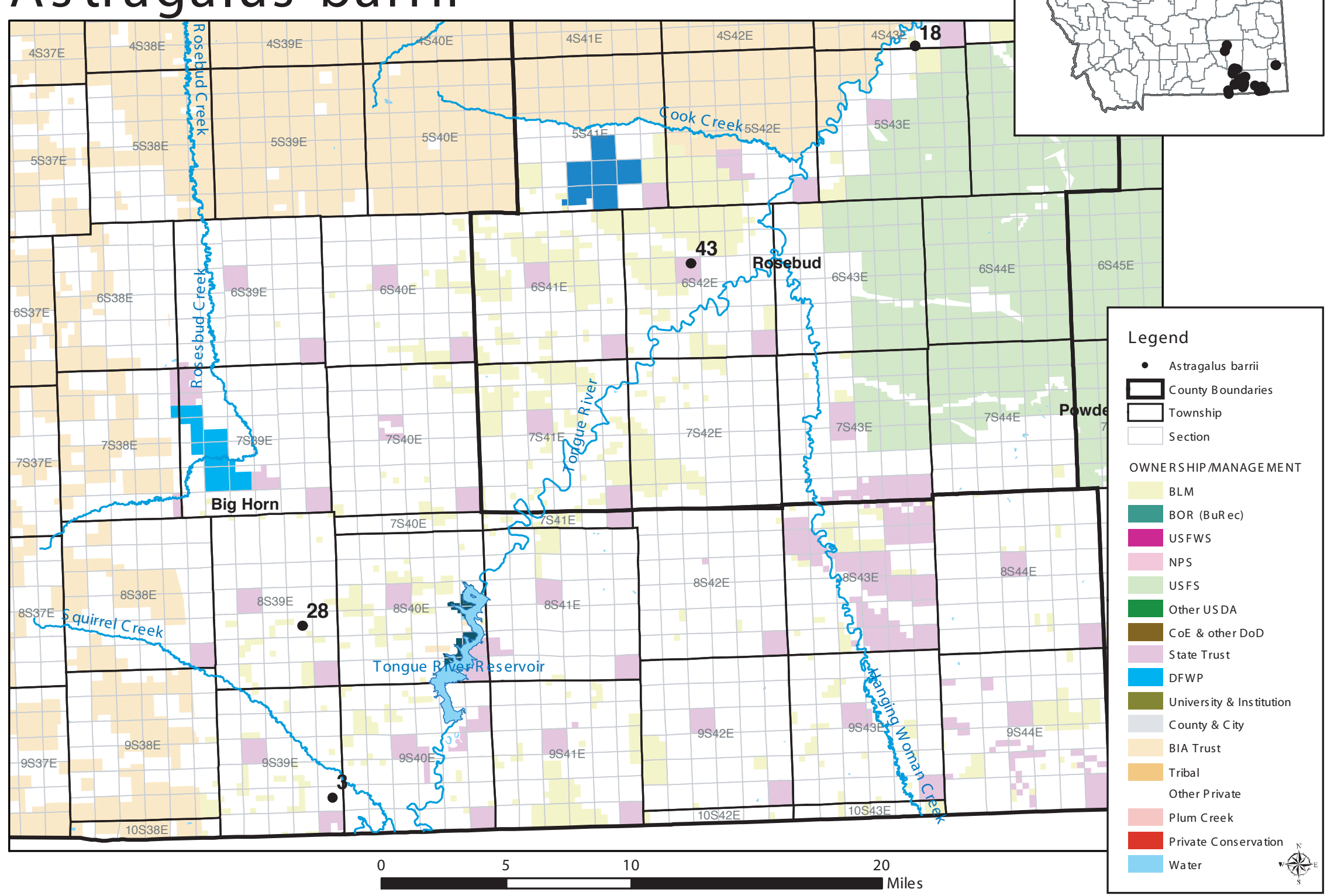

Figure 1. The four occurrence records for Astragalus barrii in the study area. There are two occurrences in eastern Big Horn County, and 12 occurrences (including one new occurrence from this study, 043) in southwestern Rosebud County. All 34 occurrences of the species in state of Montana are illustrated in the upper right hand corner of the figure. 


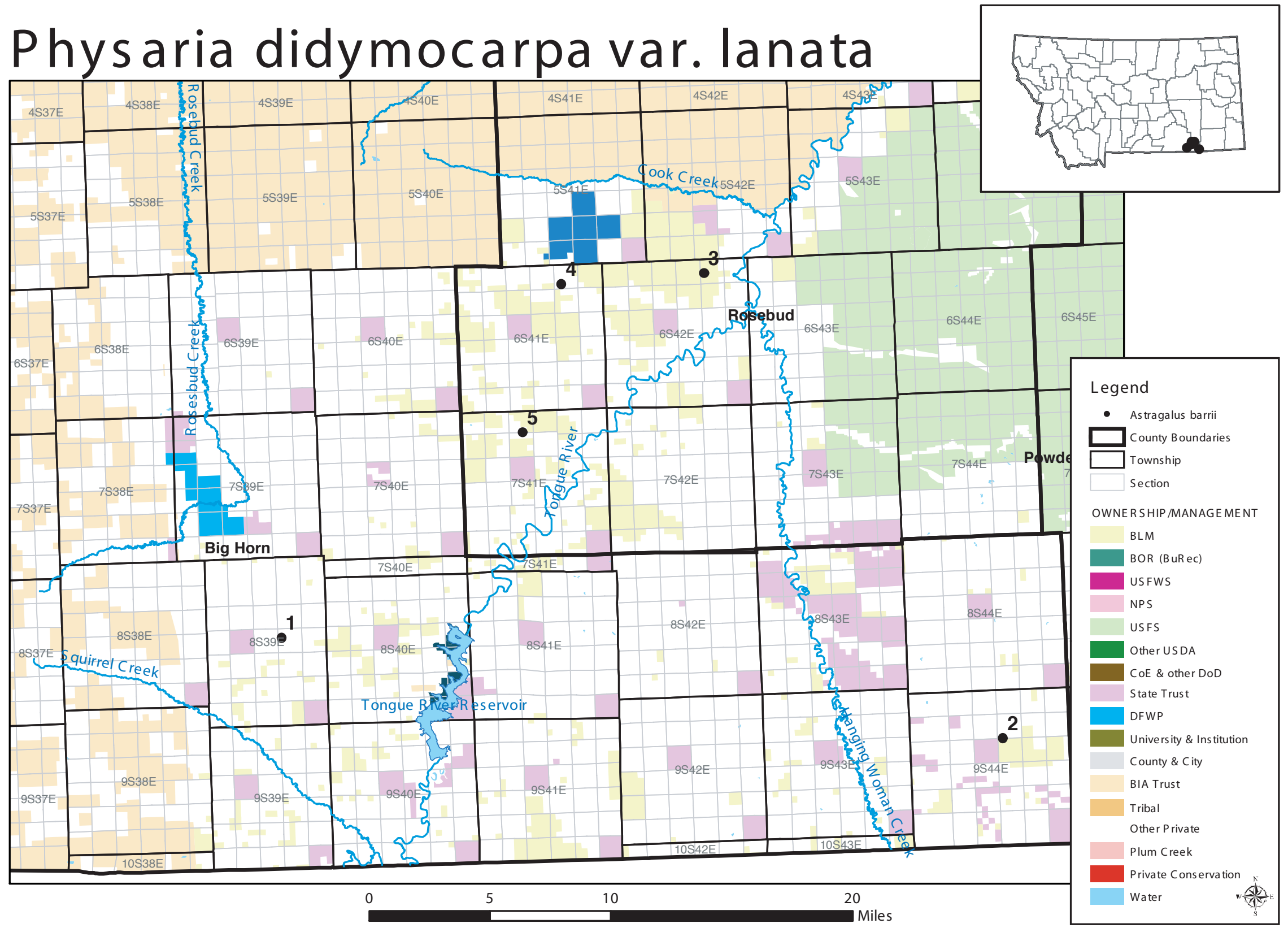

Figure 2. The five occurrence records for Physaria didymocarpa var. lanata in the study area. There are two occurrences in eastern Big Horn $\overrightarrow{0}$ County (including one new occurrence, 002), and 3 occurrences (all new, 003-005) in southwestern Rosebud County. All 5 occurrences of the species in state of Montana are illustrated in the upper right hand corner of the figure. 


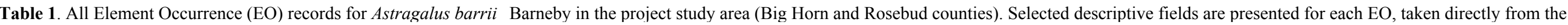
Heritage database, with new occurrences for this study highlighted in bold text.

\begin{tabular}{|c|c|c|c|c|c|c|c|c|c|c|c|}
\hline $\begin{array}{c}\text { EO } \\
\text { Number }\end{array}$ & County & Survey Site & Element Occurrence Data & General Description & $\begin{array}{c}\text { Major Land } \\
\text { Resource Area } \\
\end{array}$ & $\begin{array}{c}\text { Rangeland } \\
\text { Ecological Site }\end{array}$ & Latitude & Longitude & $\begin{array}{r}\text { Township } \\
\text { and Range }\end{array}$ & Section & TRS Note \\
\hline 003 & Big Horn & Decker & Common. & $\begin{array}{l}\text { Barren clay soil on ridgetop, with Haplopappus } \\
\text { acaulis and Eriogonum pauciflorum. }\end{array}$ & - & - & $450102 \mathrm{~N}$ & $1065349 \mathrm{~W}$ & 009S039E & 25 & NE4 \\
\hline 004 & Rosebud & Colstrip Southeast & Unknown. & $\begin{array}{l}\text { Steep butte with many roadcuts and grazing marks; on } \\
\text { border of watershed } 10100003 \text {. }\end{array}$ & - & - & $455137 \mathrm{~N}$ & $1063540 \mathrm{~W}$ & 001N041E & 11 & NE4 \\
\hline 005 & Rosebud & Miller Coulee & $\begin{array}{l}\text { Just over fence from 'Area A'. Reclamation (Big Sky } \\
\text { Strip Mine). }\end{array}$ & $\begin{array}{l}\text { On barren, decomposing sandstone cap; in sparse } \\
\text { vegetation surrounded by Pinus ponderosa, with } \\
\text { Humenopappus filifolius, others. }\end{array}$ & - & - & $454923 \mathrm{~N}$ & $1063728 \mathrm{~W}$ & $001 \mathrm{~N} 041 \mathrm{E}$ & 22 & NW4SW4 \\
\hline 015 & Rosebud & King Creek Well & $\begin{array}{l}\text { Approx. } 2,000 \text { plants, flowering prolifically. Active } \\
\text { pollination observed. }\end{array}$ & $\begin{array}{l}\text { Eroding hillside of silty-clay soil, with Artemisia } \\
\text { tridentata, Atriplex confertifolia, Yucca glauca, } \\
\text { Comandra umbellata. }\end{array}$ & - & - & $452847 \mathrm{~N}$ & $1061716 \mathrm{~W}$ & 004S044E & 22 & NW4 \\
\hline 018 & Rosebud & Gate Creek & $\begin{array}{l}\text { Approx. 200-250- plants, flowering. Evidence of } \\
\text { livestock grazing. }\end{array}$ & $\begin{array}{l}\text { Eroding knoll; with Artemisia tridentata, Atriplex } \\
\text { confertifolia and Andropogon scoparius. }\end{array}$ & - & - & $452624 \mathrm{~N}$ & $1062353 \mathrm{~W}$ & 004S043E & 34 & SE4; 35 SW4 \\
\hline 019 & Rosebud & O'Dell Creek Buttress & $\begin{array}{l}\text { Approx. } 200 \text { plants scattered atop cliff and below; } 25 \% \\
\text { flowering. }\end{array}$ & $\begin{array}{l}\text { In silty-clay soils, with Artemisia tridentata, Festuca } \\
\text { idahoensis, and Gutierrezia sarothrae. }\end{array}$ & - & - & $452735 \mathrm{~N}$ & $1062044 \mathrm{~W}$ & 004S044E & 30 & \\
\hline 027 & Rosebud & Colstrip Southeast & None. & $\begin{array}{l}\text { On sandstone hillslope (Entisol), with Pinus } \\
\text { ponderosa, Andropogon scoparius, Oryzopsis } \\
\text { hymenoides and Bromus tectorum. }\end{array}$ & - & - & $455111 \mathrm{~N}$ & $1063506 \mathrm{~W}$ & $001 \mathrm{~N} 041 \mathrm{E}$ & 12 & NW4SW4 \\
\hline 028 & Big Horn & Spring Creek & $\begin{array}{l}\text { This occurrence contains } 7 \text { subpopulations spread over } \\
\text { an area roughly } 4 \text { miles E-W by } 1.5 \text { miles N-S. Each } \\
\text { subpopulation has from } 20 \text { to } 1000 \text { plants. }\end{array}$ & $\begin{array}{l}\text { On fine, sandy-clay loam soil, above a sandstone } \\
\text { outcrop, and bare, dry fine soil or shale, with Artemisia } \\
\text { tridentata, Agropyron spicatum, Phlox hoodii, } \\
\text { Astragalus gilviflorus, Oxytropis sericea, and } \\
\text { Eriogonum spp. }\end{array}$ & - & - & $450702 \mathrm{~N}$ & $1065501 \mathrm{~W}$ & 008S039E & 23 & $\begin{array}{l}\text { NW4SE4; } 15 \text { SW4; } 16 \\
\text { SE4; } 22 \text { NE4; } 13 \text { N2; } 14 \\
\text { NE4. }\end{array}$ \\
\hline 030 & Rosebud & Stellar Creek Road & $\begin{array}{l}3 \text { small areas with approx. } 30 \text { plants total. Several plants } \\
\text { flowering. }\end{array}$ & $\begin{array}{l}\text { Sparse vegetation ( } 80 \% \text { bareground) on rocky, } \\
\text { windblown outcrops, with Artemisia tridentata, } \\
\text { Agropyron spicatum, Eriogonum pauciflorum, } \\
\text { Lesquerella alpine. }\end{array}$ & - & - & $464043 \mathrm{~N}$ & $1065417 \mathrm{~W}$ & $011 \mathrm{~N} 038 \mathrm{E}$ & 26 & \\
\hline 035 & Rosebud & Rosebud Creek & $\begin{array}{l}\text { Over } 50 \text { plants, } 10 \% \text { in late flowering, } 90 \% \text { vegetative. } \\
\text { Scattered on } 3 \text { slope segments. }\end{array}$ & $\begin{array}{l}\text { Shale outcrop ridgetops dominated by Agropyron } \\
\text { spicatum, overlying sandstone, on small escarpments } \\
\text { in rolling plains, associated species: Pinus ponderosa, } \\
\text { Rhus trilobata, Artemisia longifolia, Astragalus } \\
\text { gilviflorus. }\end{array}$ & - & - & $455022 \mathrm{~N}$ & $1062737 \mathrm{~W}$ & $001 \mathrm{~N} 042 \mathrm{E}$ & 13 & W2 \\
\hline 038 & Rosebud & Davidson Coulee & 6 plants in 2 sub-populations, in vegetative condition. & $\begin{array}{l}\text { Midslope outcrops on sandstone and overlying shale on } \\
\text { north aspect of east-west trending ridges above Rosebud } \\
\text { Creek. In Pinus ponderosa /Agropyron spicatum } \\
\text { habitat type. Associated species: Juniperus } \\
\text { scopulorum, Astragalus gilviflorus, Carex filifolia. }\end{array}$ & - & - & $454207 \mathrm{~N}$ & $1064009 \mathrm{~W}$ & 002S041E & 4 & NE4 \\
\hline 040 & Rosebud & Big Porcupine Creek & None provided. & $\begin{array}{l}\text { Prominent escarpment above the southwest side of } \\
\text { Porcupine Creek, on a midslope finger ridge dominated } \\
\text { by Agropyron spicatum. }\end{array}$ & - & - & $462824 \mathrm{~N}$ & $1070111 \mathrm{~W}$ & $008 \mathrm{~N} 038 \mathrm{E}$ & 6 & SE4SW4 \\
\hline 041 & Rosebud & Bridge Creek & $\begin{array}{l}\text { Seven subpopulations with } 50-200 \text { individuals, at least } \\
700 \text { individuals in all. None in flower or fruit ( } 1 \\
\text { peduncle seen). }\end{array}$ & $\begin{array}{l}\text { Sparsely vegetated slopes. Associated plant community: } \\
\text { Eriogonum pauciflorum, Agropyron spicatum, } \\
\text { Agropyron dasystachyum, Artemesia tridentata, } \\
\text { Gutierrezia sarothrae. Associated plants: Grindellia } \\
\text { squarrosa, Astragalus giviflorus, Machaeranthera } \\
\text { grindelioides, Eriogonum flavum. }\end{array}$ & - & - & $453122 \mathrm{~N}$ & $1061516 \mathrm{~W}$ & 004S044E; & 02 & NE4NE4; SW4; NW4 \\
\hline 043 & Rosebud & Whitten Creek & $\begin{array}{l}4 \text { major mats/clumps (approx. } 12 \mathrm{~cm} \text { wide) on knob. } \\
\text { Fruiting with some remnant flowers. }\end{array}$ & $\begin{array}{l}\text { Ponderosa pine - Rocky Mountain juniper; hills of } \\
\text { red shale and sandstone, and badlands. NW-facing } \\
\text { knob of badlands, very sparsely vegetated. An } \\
\text { occasional greasewood shrub, juniper or ponderosa } \\
\text { pine; bluebunch wheatgrass present. Associated } \\
\text { species include Sarcobatus vermiculatus, Pinus } \\
\text { ponderosa, Juniperus scopulorum, Cryptantha sp., } \\
\text { Agropyron spicatum; Astragalus gilviflorus common } \\
\text { on same hills. }\end{array}$ & $\begin{array}{l}\text { Eastern } \\
\text { Sedimentary } \\
\text { Plains, 58AE }\end{array}$ & Badlands (BL) & $451908 \mathrm{~N}$ & $1063519 W$ & 006S042E & 16 & NE4 \\
\hline
\end{tabular}




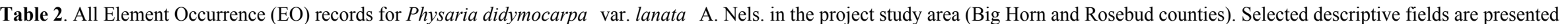
for each EO, taken directly from the Heritage database, with new occurrences for this study highlighted in bold text.

\begin{tabular}{|c|c|c|c|c|c|c|c|c|c|c|c|}
\hline $\begin{array}{c}\text { EO } \\
\text { Number }\end{array}$ & County & Survey Site & Element Occurrence Data & General Description & $\begin{array}{c}\text { Major Land } \\
\text { Resource Area }\end{array}$ & $\begin{array}{c}\text { Rangeland } \\
\text { Ecological Site }\end{array}$ & Latitude & Longitude & $\begin{array}{c}\text { Township } \\
\text { and Range }\end{array}$ & Section & TRS Note \\
\hline 001 & Big Horn & Spring Creek & $\begin{array}{l}\text { 2001: locally abundant; } 90 \% \text { flowering, } 10 \% \text { basal } \\
\text { rosette only. Size of occupied area is similar to } 1993 \\
\text { estimate. 1993: flowering mostly in May, but a few } \\
\text { plants still flowering in August. Locally abundant, } 1000 \text {. } \\
2000 \text { plants. }\end{array}$ & $\begin{array}{l}\text { 1993: "scoria" and sometimes shale substrate. 2001: } \\
\text { steep southwest-facing slope of red scoria and shale } \\
\text { substrate; hills rise from Spring Creek bottomland. } \\
\text { Characteristic associated species include Stipa comata, } \\
\text { Agropyron spicatum, Oryzopsis hymenoides, Phlox } \\
\text { hoodii. Other common species include: Chaenactis } \\
\text { douglasii, Sphaeralcea coccinea. }\end{array}$ & - & - & $450804 \mathrm{~N}$ & $1065533 \mathrm{~W}$ & 008S039E & 14 & $\mathrm{~N} 2 ; 22 \mathrm{E} 2$ \\
\hline 002 & Big Horn & Tidwell Draw & $\begin{array}{l}\text { Over } 100 \text { individuals covering entire south-facing } \\
\text { exposure; } 95 \% \text { fruiting; }<5 \% \text { vegetative. } 5 \text { or } 6 \text { large } \\
\text { individuals }(>20 \mathrm{~cm} \text { wide with fruits). }\end{array}$ & $\begin{array}{l}\text { Steep, sandy, south-facing slope above draw with } \\
\text { sandstone outcrops and fragments; fairly productive } \\
\text { slope - high grass cover. Shrubs and grass } \\
\text { community with an occasional Juniperus } \\
\text { scopulorum or Pinus ponderosa. Grasses dominate: } \\
\text { Stipa comata, Agropyron spicatum, Bromus } \\
\text { japonicus. Shrubs: Rhus trilobata, Artemisia } \\
\text { tridentata, Ceratoides lanata, Astragalus gilviflorus, } \\
\text { Yucca glauca, Opuntia polyacantha. }\end{array}$ & $\begin{array}{c}\text { Eastern } \\
\text { Sedimentary } \\
\text { Plains, } 58 \mathrm{AE}\end{array}$ & Thin Breaks (TB) & $450330 \mathrm{~N}$ & $1061909 \mathrm{~W}$ & 009S044E & 15 & $\begin{array}{l}\text { NW4; } 10 \\
\text { SE4SW4 }\end{array}$ \\
\hline 003 & Rosebud & Zook Creek & $\begin{array}{l}\text { Approximately } 50 \text { individuals; } 20 \% \text { fruiting, } 80 \% \\
\text { vegetative (basal rosettes only). Doesnít occur in } \\
\text { areas of slope that are significantly composed of red } \\
\text { shale. }\end{array}$ & $\begin{array}{l}\text { Southwest-facing slope of redbed shale and sand east } \\
\text { of creek. Red shale and sand slope below sandstone } \\
\text { outcrop. Moderately steep slope. Open slope of } \\
\text { Pinus ponderosa and Juniperus scopulorum; bunch } \\
\text { grasses and shrubs also common. Associated species } \\
\text { include Pinus ponderosa, Juniperus scopulorum; } \\
\text { shrubs: Yucca glauca, Rhus trilobata, Atriplex } \\
\text { confertifolia; grasses: Agropyron spicatum, Stipa } \\
\text { comata, Bouteloua curtipendula; Forbs: Gaura } \\
\text { coccinea, Sphaeralcea coccinea, Psoralea sp. }\end{array}$ & $\begin{array}{c}\text { Eastern } \\
\text { Sedimentary } \\
\text { Plains, 58AE }\end{array}$ & Coarse Clay (CC) & $452032 \mathrm{~N}$ & $1063325 \mathrm{~W}$ & 006S042E & 2 & $\begin{array}{l}\text { NW4SW4; } 3 \\
\text { NE4NW4 }\end{array}$ \\
\hline 004 & Rosebud & Bull Creek & $\begin{array}{l}\text { Fairly abundant; } 16 \text { individuals in one area, } \\
\text { occupying approx. } 20 \text { square feet. }\end{array}$ & $\begin{array}{l}\text { Sandy, rocky, southwest-facing slope of roadcut, } \\
\text { clinker-shale mix, sparsely vegetated. Southwest- } \\
\text { facing slope adjacent to 2-track road. Loose, sandy } \\
\text { shale. Dominated by grasses; interspersed with } \\
\text { Rhus trilobata and Artemisia cana. Associated } \\
\text { species include } \text { Agropyron spicatum, Artemisia cana, } \\
\text { Artemisia frigida, Rhus trilobata, and Eriogonum }\end{array}$ & $\begin{array}{c}\text { Eastern } \\
\text { Sedimentary } \\
\text { Plains, 58AE }\end{array}$ & Coarse Clay (CC) & $452025 \mathrm{~N}$ & $1064042 \mathrm{~W}$ & 006S041E & 2 & S2SW4 \\
\hline 005 & Rosebud & Canyon Creek & $\begin{array}{l}19 \text { individuals occuping approx. } 100 \text { square yards. } \\
95 \% \text { fruiting, } 5 \% \text { vegetative. }\end{array}$ & $\begin{array}{l}\text { Generally barren sandstone outcrops; calcium } \\
\text { carbonate present; south-facing slope. Rocky } \\
\text { Mountain juniper above, rabbit brush and silver } \\
\text { sage on slope. Shrubs dominate: Chrysothamnus } \\
\text { nauseosus, Artemisia cana, Rhus trilobata. } \\
\text { Associated species: previously mentioned plus } \\
\text { Agropyron spicatum. }\end{array}$ & $\begin{array}{c}\text { Eastern } \\
\text { Sedimentary } \\
\text { Plains, 58AE }\end{array}$ & Badlands (BL) & $451508 \mathrm{~N}$ & $1064256 \mathrm{~W}$ & 007S041E & 9 & NW4NE4 \\
\hline
\end{tabular}




\section{Appendix 1}

Pertinent Biological Information for Astragalus barrii and Physaria didymocarpa var. lanata 
Information on Astragalus barrii has been largely taken from Heidel and Marriott (1996), unless otherwise noted. Information on Physaria didymocarpa var. lanata has been largely taken from the Montana Natural Heritage Program database, unless otherwise noted.

\section{Astragalus barrii Barneby (Barr's milkvetch); Fabaceae}

\section{Species Description}

A. barrii forms dense mats (cushions), which rarely exceed $25.9 \mathrm{~cm}$ in height. Prostrate woody stems give rise to numerous leaves, each made up of narrowly elliptic leaflets that are $1-4 \mathrm{~cm}$ long. Both the stems and leaves of $A$. barrii are densely covered with short, white hairs. Iridescent bluish-purple to pinkish-purple flowers arise on short stalks $(7-16 \mathrm{~mm})$ throughout the mats on narrow, open, (1) 2-4 flowered inflorescences. The petals are 7-17 $\mathrm{mm}$ long. The calyx is 3-5 $\mathrm{mm}$ long and densely covered with long, white hairs. The sparsely white-hairy pod is narrowly elliptical, 4-8 $\mathrm{mm}$ long, and 1-2 $\mathrm{mm}$ wide. In Montana, this species blooms from late April to mid-June and later forms narrow, egg-shaped, one- to few-seeded pods. A. barrii may remain in a vegetative condition under stressful conditions.

Key Identification Factors

Flowers are necessary to distinguish A. barrii from similar Astragalus species. The species is distinctive for its small, iridescent, bluish-purple to bluish-pink, early-blooming flowers. Petal color may fade, sometimes to yellowish white, as flowers dry (Taylor pers. obs).

Habitat

This species occurs on heavy clay ("gumbo") knobs, badlands, buttes and barren hilltops, often on calcareous soft shale and siltstone substrates (Heidel \& Marriott 1996). The calcareous clay soils on which A. barrii occurs are likely to be low in organic matter, as these locations are sparsely vegetated (Schassberger 1990). Habitats are characterized by a low vegetative cover, with Pinus ponderosa (ponderosa pine), Juniperus scopulorum (Rocky Mountain Juniper), Artemisia tridentata (sagebrush) and Agropyron spicatum (bluebunch wheatgrass) as common associates (Heidel \& Marriott 1996). Elevation range is 3,140-4,160 f.a.s.l.

Populations of $A$. barrii are associated with the harsh edaphic and environmental conditions of Badlands areas. These areas receive limited rainfall and are subject to high light intensities, potentially limiting plant establishment and survival as a result of high soil water evaporation. This species often occurs on barren, eroded microsites and may depend on the climate that maintains these sites. At some locations, particularly steep slopes, the soils erode during intense rain storms. Because of its cushion habit and dense foliage, soil is protected from water erosion beneath $A$. barrii plants, resulting in individuals that are frequently perched atop small pedestals of soil (Heidel \& Marriott 1996).

The species is found in Koppen's BSw climatic zone, a steppe climate east of the Continental Divide that is typified by cold, dry winters, and convective summer storms. In southeastern Montana, the regional climate is characterized by hot, dry summers. Spring rains bring the highest amount of precipitation, while summer storms are largely convective, delivering less precipitation. Winters are cold and dry, with precipitation occurring mostly in the form of snow (Schassberger 1990). 
Major Land Resource Area (as defined by this study)

Eastern Sedimentary Plains, 58AE

Ecological sites (as defined by this study):

Type: Rangeland; Site Names include Clayey (Cy), Shallow Clay (SwCy) and Badlands (BL).

Similar Species

Four other matt-forming, 3-leaflet Astragalus species overlap geographically with A. barrii in Montana. These are A. aretioides (cushion milkvetch), A. sericoleucus (silky milkvetch), A. gilviflorus (plains milkvetch) and A. hyalinus (summer milkvetch).

A. aretioides and A. sericoleucus have flowers that are typically one half the size of A. barrii, and tend to have denser mats. Both species are known from Big Horn County, but were not encountered during the survey.

A. gilviflorus and A. hyalinus typically have larger, cream to whitish flowers. They also differ from $A$. barrii by having a longer calyx tube $(6-16 \mathrm{~mm})$ and absent or shorter $(<3.5 \mathrm{~mm})$ penduncles (calyx length 2.8-5 mm, peduncle length 7-24 mm). Known in Montana from the Pryor Mountains and from the Ashland District of the Custer National Forest, A. hyalinus is similar in growth habit to A. barrii and is found in similar habitats.

The only similar looking Astragalus species observed during this survey was A. gilviflorus (see Appendix 3.5). This species is very abundant in the study area occurring in the same habitat and locations as A. barrii. The majority of A. gilviflorus plants were at the end of their blooming period. Vegetatively, A. gilviflorus appears more robust with longer leaf petioles and larger leaflets than A. barrii. The flowers, when present, are distinctly larger than those of A. barrii.

Present Legal or Other Formal Status

US Fish and Wildlife Service (USFWS): None. Previously a Category C3, signifying that the species has "proven to be more abundant or widespread than previously believed and/or...(is) not subject to any identifiable threat".

US Forest Service (USFS): Sensitive

BLM: Watch

MTNHP: G3 S3 (imperiled or vulnerable in the state). State ranking reasons: A regional endemic with 34 occurrences, occurring on fragmented and localized habitats on the landscape (Heidel \& Vanderhorst 1999). With fewer than 100 occurrences, the species would typically be considered "imperiled" however almost half of its known occurrences are on national forest lands, where it is recognized as "sensitive", and where habitat threats are limited. Low-level potential threats exist from coal bed methane, mining and other development activities, as well as from grazing and herbicide application (Schassberger 1990; Heidel \& Vanderhorst 1999; Taylor pers. obs.).

Distribution

A regional endemic of southwestern South Dakota, northeastern Wyoming and southeastern Montana. State Distribution is limited to southeastern Montana. Total number of state occurrences is 34, from Big Horn (2), Rosebud (12, includes 1 new occurrence from this survey), Powder River (19) and Carter (1) Counties. 


\section{Physaria didymocarpa var. lanata A. Nels. (wooly twinpod); Brassicaceae}

Species Description

Reprinted from Fertig (1992): P. didymocarpa var. lanata is a tufted, multi-stemmed perennial herb covered with long-stalked, tangled, multi-branched woolly hairs (giving the entire plant a gray appearance). Basal leaves are entire to coarsely dentate and shaggy-margined due to the long-stalked pubescence. Stem leaves are shorter, oblanceolate, and 1-2 cm long. The inflorescence consists of a congested cluster of yellow, 4-petaled flowers 8-12 mm long. Mature fruits consist of 2 inflated, balloon-like pods with shaggy pubescence. The replum of the mature fruit is narrowly lance-shaped to oblanceolate with 2 stubby funiculi (stalks connecting ovule to placenta) per face. Flowers from May-June, with fruits produced as late as September.

Key Identification Factors

Leaf pubescence (long, tangled, spreading hairs, especially at leaf bases) is sufficient for identification.

Habitat

Sandstone outcrops, redbed clay (clinker or scoria)-shale slopes, calcareous substrates, and road cuts; in open shrub-dominated slopes, sometimes with a sparse cover of ponderosa pine (Pinus ponderosa) and Rocky Mountain juniper (Juniperus scopulorum). Bluebunch wheatgrass (Agropyron spicatum) is a common associate. Elevation: 3300-4100 f.a.s.1.

Major Land Resource Area (as defined by this study) Eastern Sedimentary Plains, 58AE

Ecological sites (as defined by this study)

Type: Rangeland; Site Names include Coarse Clay (CC) and Badlands (BL) and Thin Breaks (TB).

Similar Species

Many similar Physaria species exist in Montana. A microscope or hand lens, technical keys and reference to herbarium specimens are recommended for positive identification. P. didymocarpa var. didymocarpa (common twinpod) has appressed hairs on the basal leaves (giving them a smooth look), and there are mostly 3-6 ovules/funiculi per locule. P. acutifolia (sharp-leaf twinpod) also has leaves with appressed hairs. P. brassicoides (double twinpod) is most similar to $P$. didymocarpa var. lanata. In eastern Montana it occurs on clay hills and road cuts. It has appressed leaf hairs and a narrowly linear fruit partition whereas $P$. didymocarpa var. lanata has shaggy hairs and narrowly lanceolate to oblanceolate partitions. (Dorn 1992; Fertig 1992).

Present Legal or Other Formal Status

USFWS: None

USFS: None

BLM: None

MTNHP: G5T2 S1. State ranking reasons: A regional endemic which is known from 5 occurrences in the state, from East Big Horn and Rosebud counties. One of the populations in East Big Horn county numbers over one thousand individuals, however occurrences typically have low population densities (ranging from 16-100 individuals) and occupy fragmented and 
localized habitats on the landscape. Low-level potential threats exist from coal bed methane, mining and other development activities, as well as from grazing and herbicide application (Schassberger 1990; Heidel \& Vanderhorst 1999; Taylor pers. obs.). The species has only recently been documented in the state (first observation 1993), and requires the documentation of baseline information and monitoring.

\section{Distribution}

A Regional endemic of north-central Wyoming and adjacent Montana. Statewide distribution is limited to southeastern Montana. Total number of state occurrences is 5 (includes 4 new locations from this survey), from Big Horn (2) and Rosebud (3) Counties. 


\section{Appendix 2}

Potential and Existing Habitat for Astragalus barrii and Physaria didymocarpa var. lanata

Solid black lines indicate search routes. Solid red lines represent potential habitat that was identified in the field but not surveyed because of access or time limits. Astragalus barrii locations are marked by black stars, whereas Physaria didymocarpa var. lanata locations are marked by black dots.

The 1:24,000 USGS Quad names and codes associated with each map are as follows:

Quad Name Quad Code

\begin{tabular}{|c|c|c|}
\hline Map 1: & Half Moon Hill & 4510628 \\
\hline & Pearl School & 4510618 \\
\hline Map 2: & Spring Gulch & 4510626 \\
\hline & Holmes Ranch & 4510616 \\
\hline & Lacey Gulch & 4510625 \\
\hline Map 3: & Stroud Creek & 4510624 \\
\hline & Forks Ranch & 4510614 \\
\hline & Quietus & 4510613 \\
\hline Map 4: & Clubfoot Creek & 4510645 \\
\hline & Birney & 4510635 \\
\hline & Birney SW & 4510636 \\
\hline & Spring Gulch & 4510626 \\
\hline & Taintor Desert & 4510637 \\
\hline & Tongue River Dam & 4510627 \\
\hline Map 5: & Half Moon Hill & 4510628 \\
\hline & Pearl School & 4510618 \\
\hline
\end{tabular}




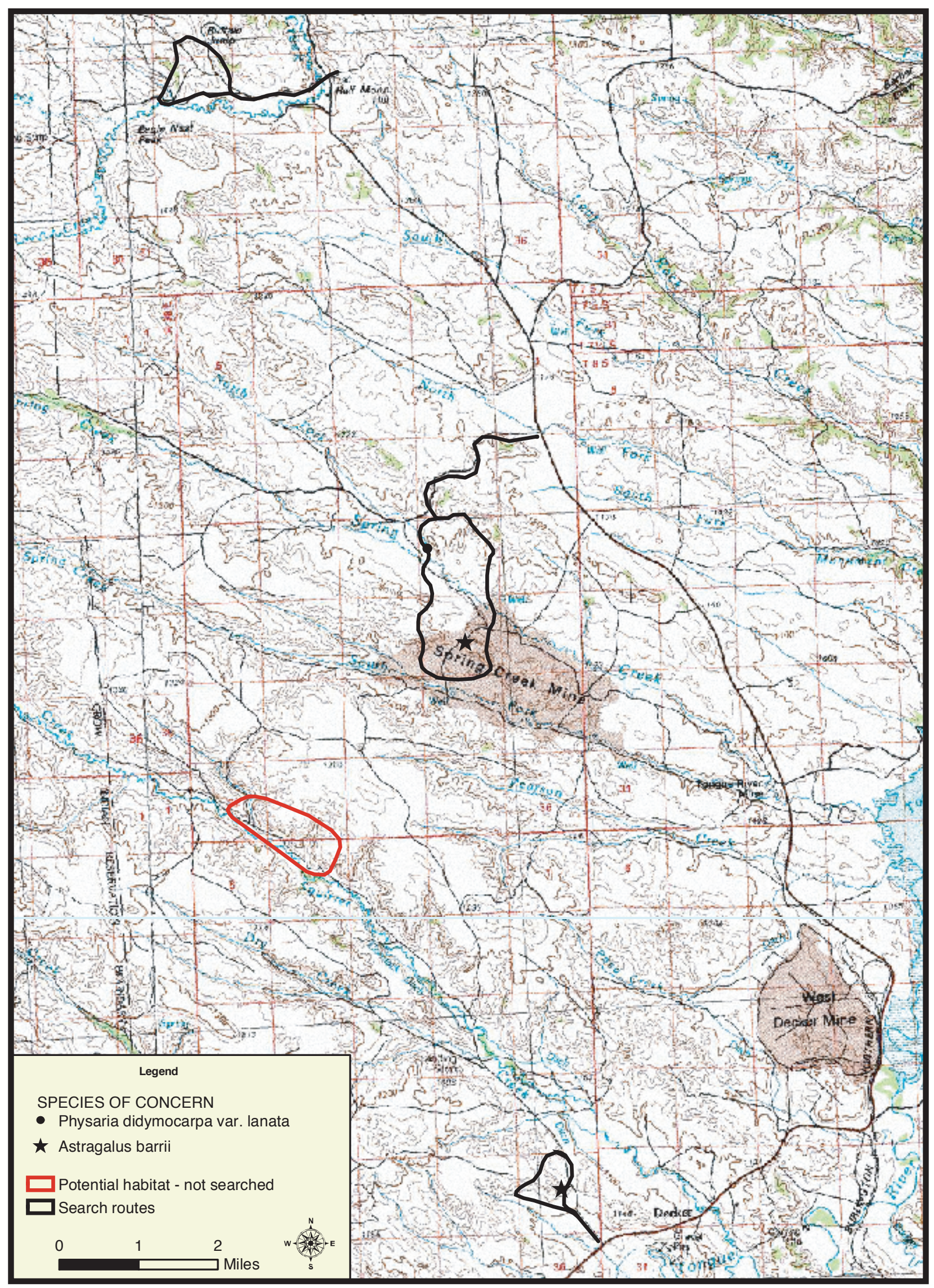

Appendix 2.1. Potential and existing habitat for Astragalus barrii and Physaria didymocarpa var. lanata. Solid black lines indicate search routes, whereas solid red lines represent potential habitat that was identified in the field but not surveyed because of access or time limits. A. barrii locations are marked by black stars, whereas $P$. didymocarpa var. lanata locations are marked by black dots. This 1:24,000 USGS Quad map is comprised of the Quads Half Moon Hill (4510628) and Pearl School (4510618). 


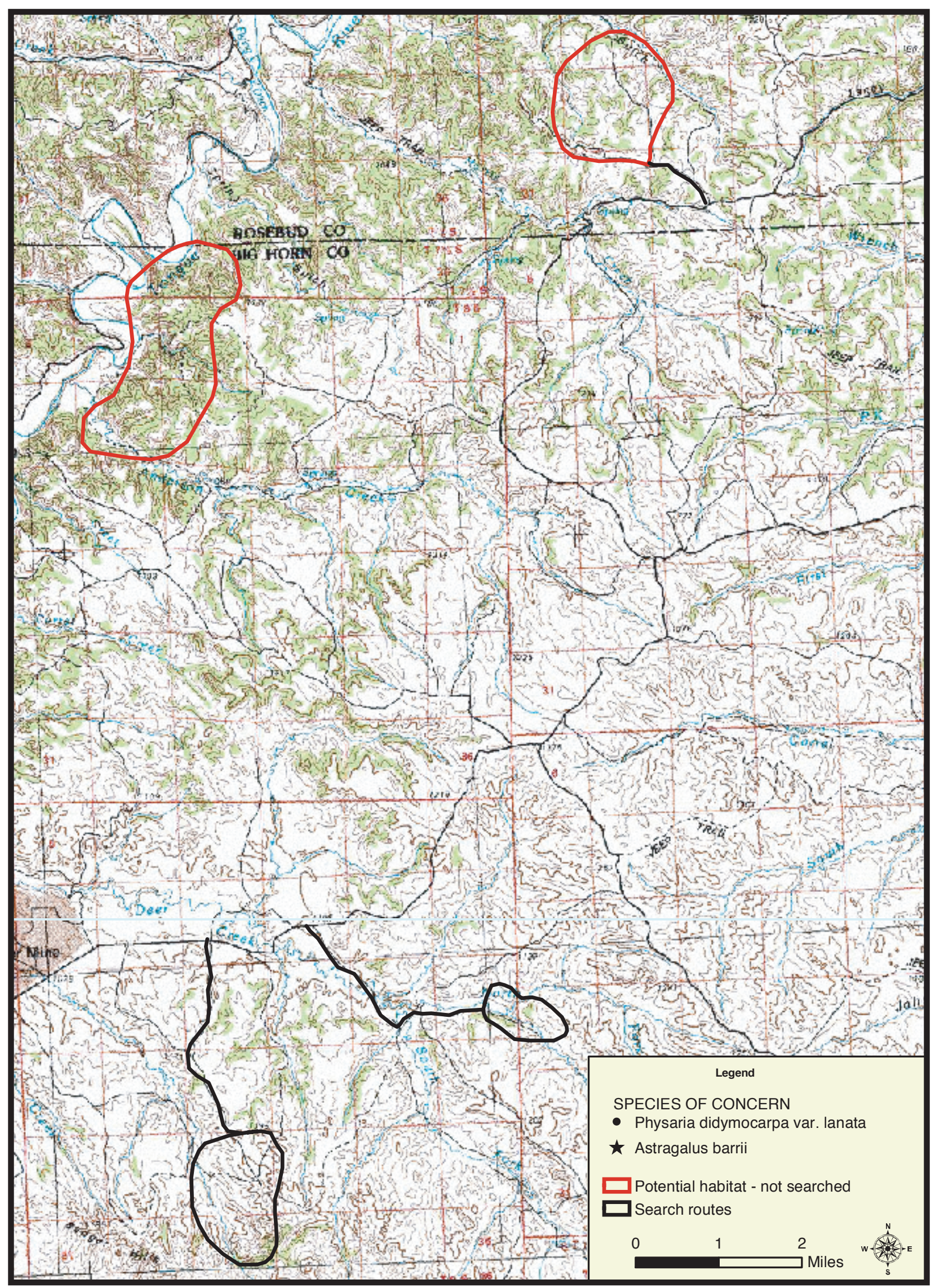

Appendix 2.2. Potential and existing habitat for Astragalus barrii and Physaria didymocarpa var. lanata. Solid black lines indicate search routes, whereas solid red lines represent potential habitat that was identified in the field but not surveyed because of access or time limits. A. barrii locations are marked by black stars, whereas $P$. didymocarpa var. lanata locations are marked by black dots. This 1:24,000 USGS Quad map is comprised of the Quads Spring Gulch (4510626), Holmes Ranch (4510616) and Lacey Gulch (4510625). 


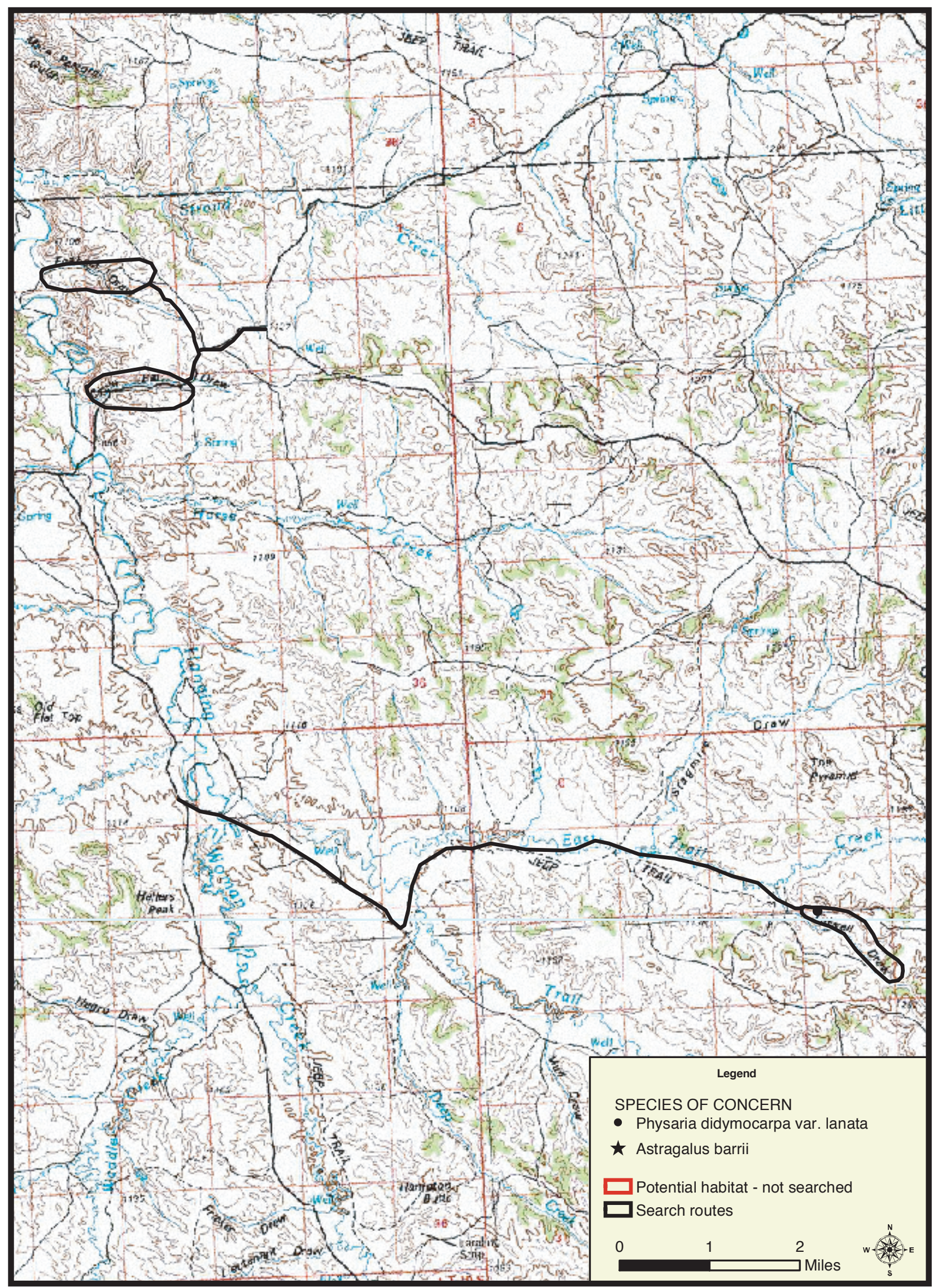

Appendix 2.3. Potential and existing habitat for Astragalus barrii and Physaria didymocarpa var. lanata. Solid black lines indicate search routes, whereas solid red lines represent potential habitat that was identified in the field but not surveyed because of access or time limits. A. barrii locations are marked by black stars, whereas $P$. didymocarpa var. lanata locations are marked by black dots. This 1:24,000 USGS Quad map is comprised of the Quads Stroud Creek (4510624), Forks Ranch (4510614) and Quietus (4510613). 


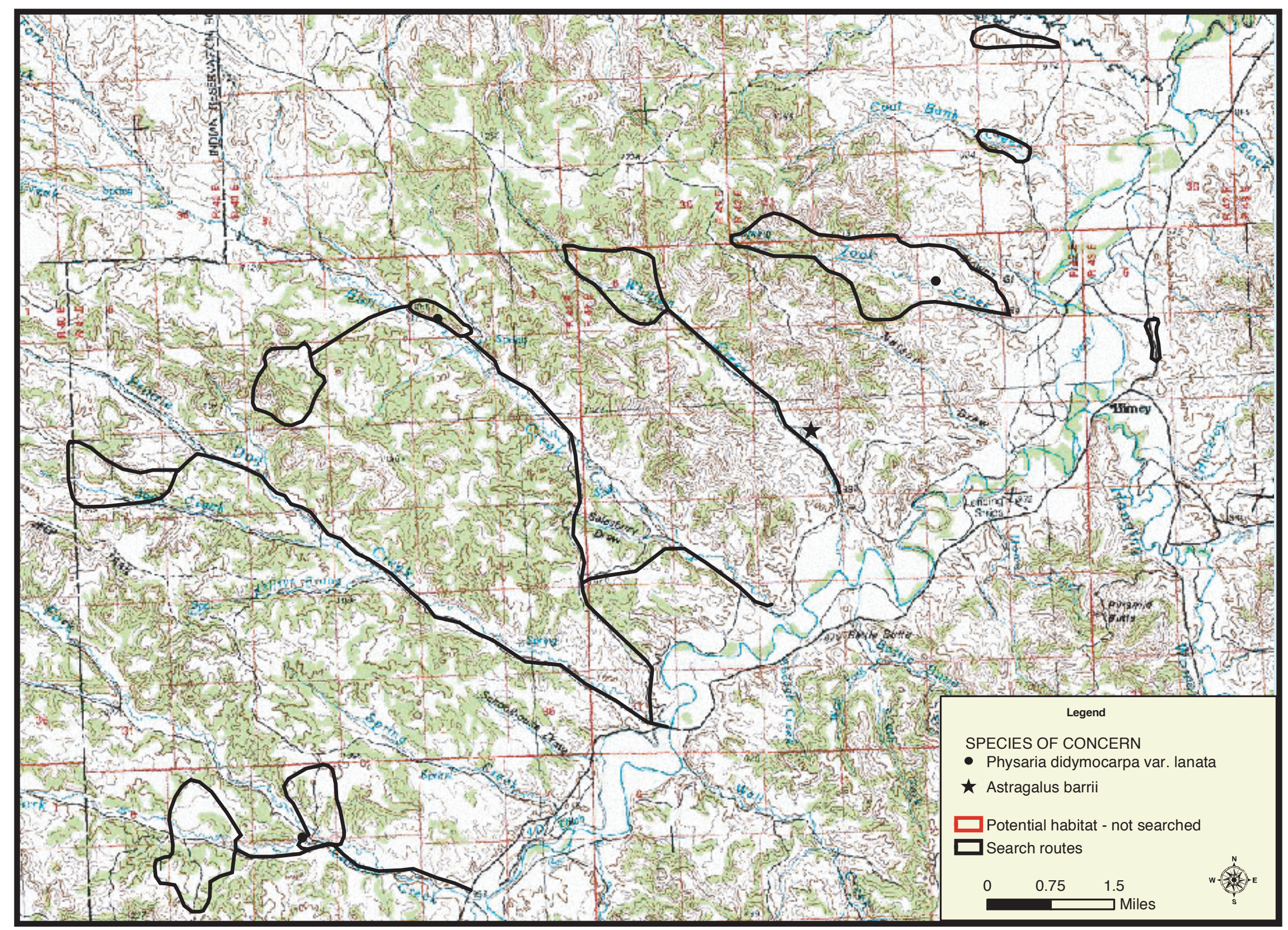

Appendix 2.4. Potential and existing habitat for Astragalus barrii and Physaria didymocarpa var. lanata. Solid black lines indicate search routes, whereas solid red lines represent potential habitat that was identified in the field but not surveyed because of access or time limits. A. barrii locations are marked by black stars, whereas P. didymocarpa var. lanata locations are marked by black dots. This 1:24,000 USGS Quad map is comprised of the Quads Clubfoot Creek (4510645), Birney (4510635), Birney SW (4510636), Spring Gulch (4510626), Taintor Desert (4510637) and Tongue River Dam (4510627). 


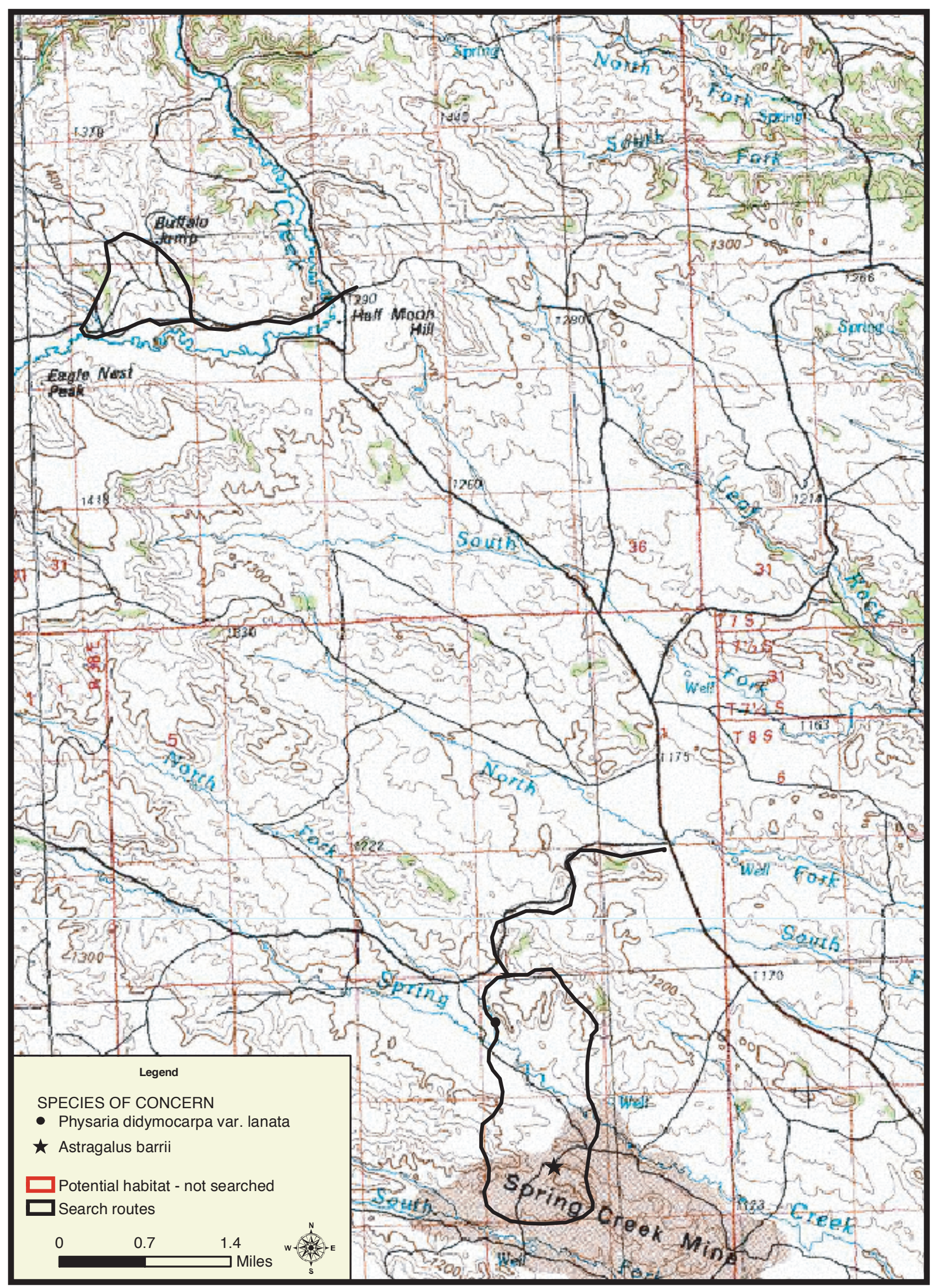

Appendix 2.5. Potential and existing habitat for Astragalus barrii and Physaria didymocarpa var. lanata. Solid black lines indicate search routes, whereas solid red lines represent potential habitat that was identified in the field but not surveyed because of access or time limits. A. barrii locations are marked by black stars, whereas $P$. didymocarpa var. lanata locations are marked by black dots. This 1:24,000 USGS Quad map is comprised of the Quads Half Moon Hill (4510628) and Pearl School (4510618). 
Appendix 3

Selected Plant and Habitat Photographs 


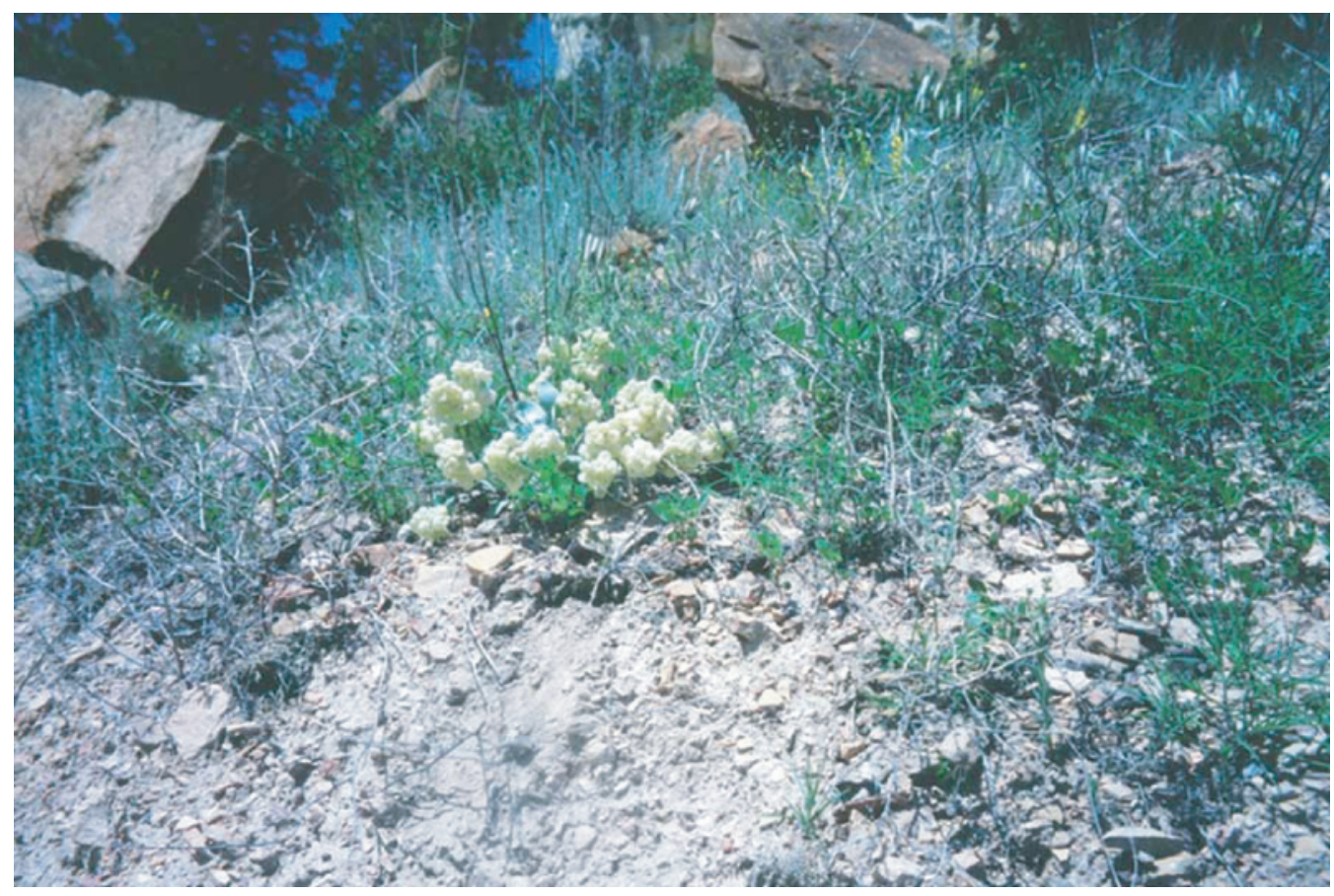

Appendix 3.1. Physaria didymocarpa var. lanata (wooly twinpod) with inflated fruits. Photo taken June 19, 2001, T6S R41E S2, Bull Creek, Rosebud County, Montana.

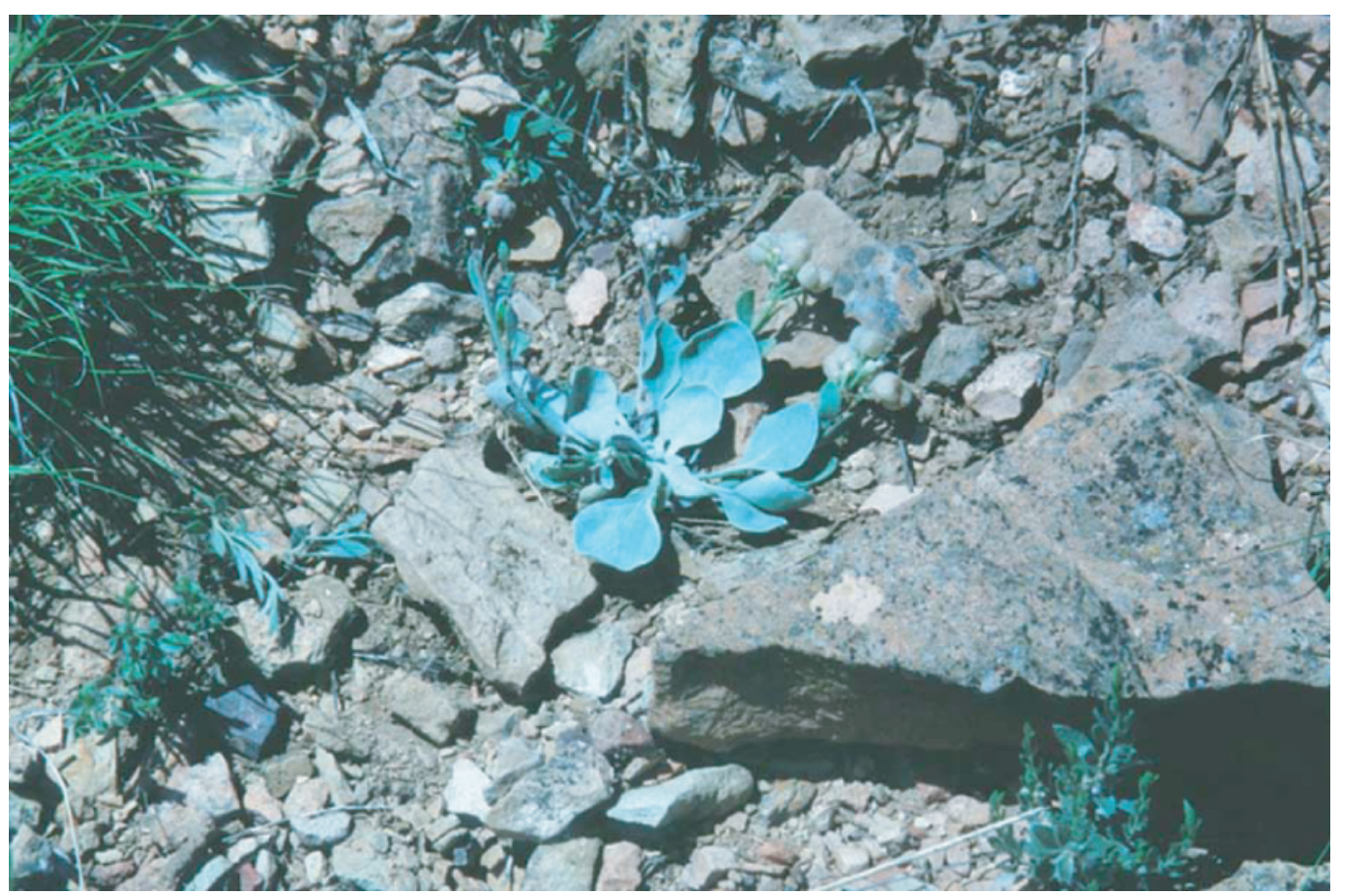

Appendix 3.2. Physaria didymocarpa var. lanata (wooly twinpod) basal rosette and fruits. Photo taken June 20, 2001, T6S R42E S2, Zook Creek, Rosebud County, Montana. 


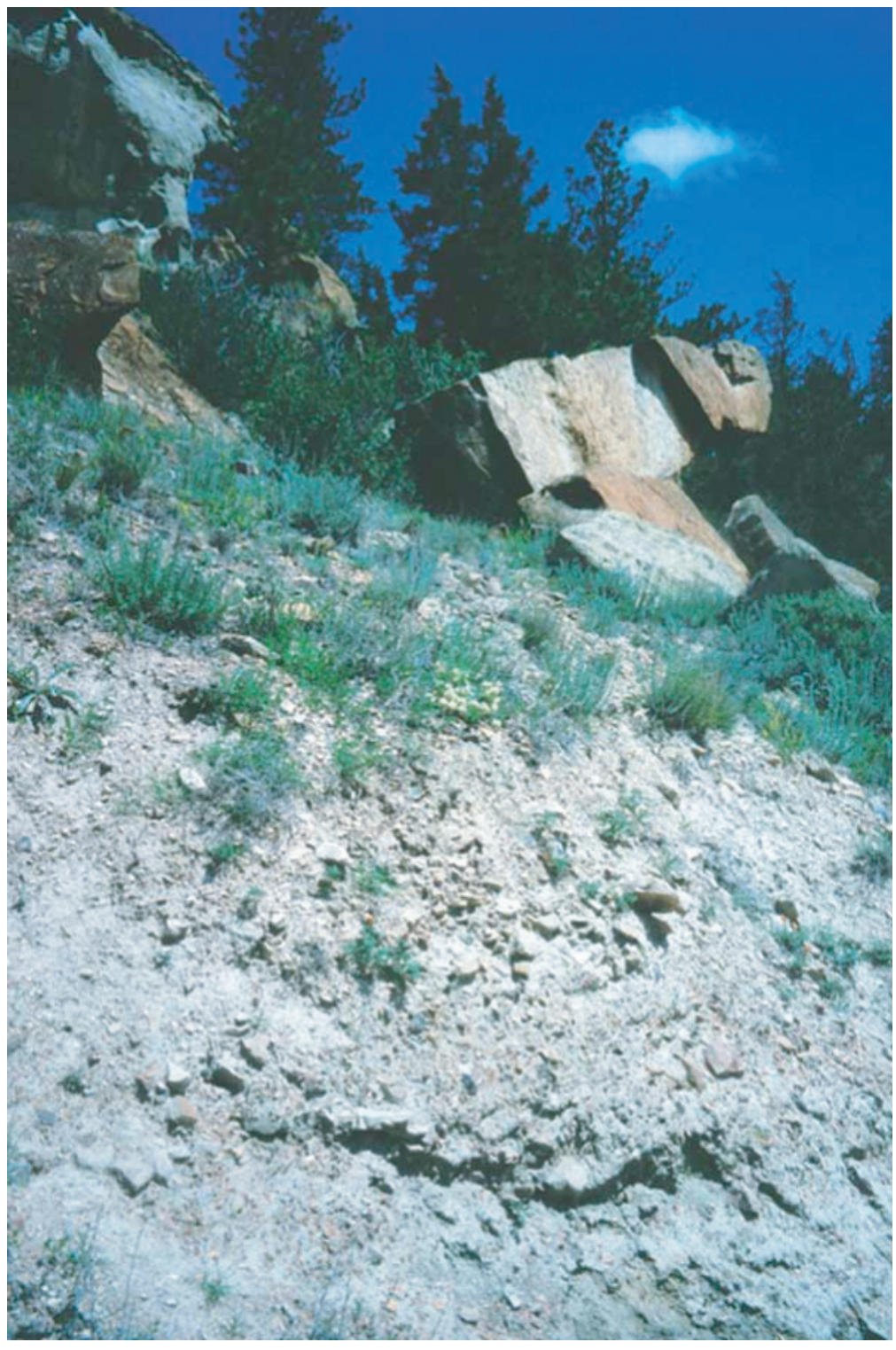

Appendix 3.3. Physaria didymocarpa var. lanata (wooly twinpod) habitat. Photo taken June 19, 2001, T6S R41E S2, Bull Creek, Rosebud County, Montana. 


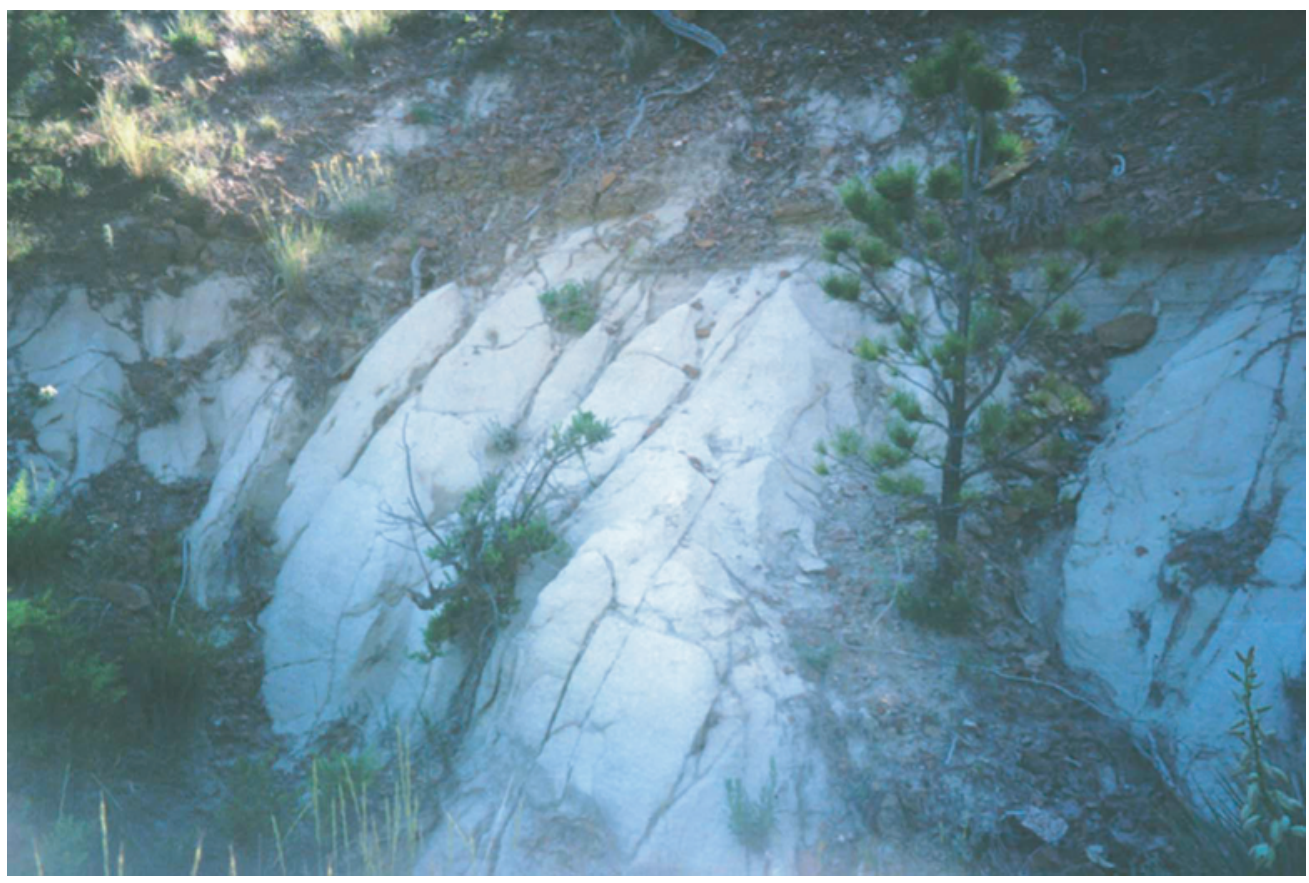

Appendix 3.4. Astragalus barrii (Barrís milkvetch) habitat. Photo taken June 22, 2001, T6S R42E S16, Whitten Creek, Rosebud County, Montana.

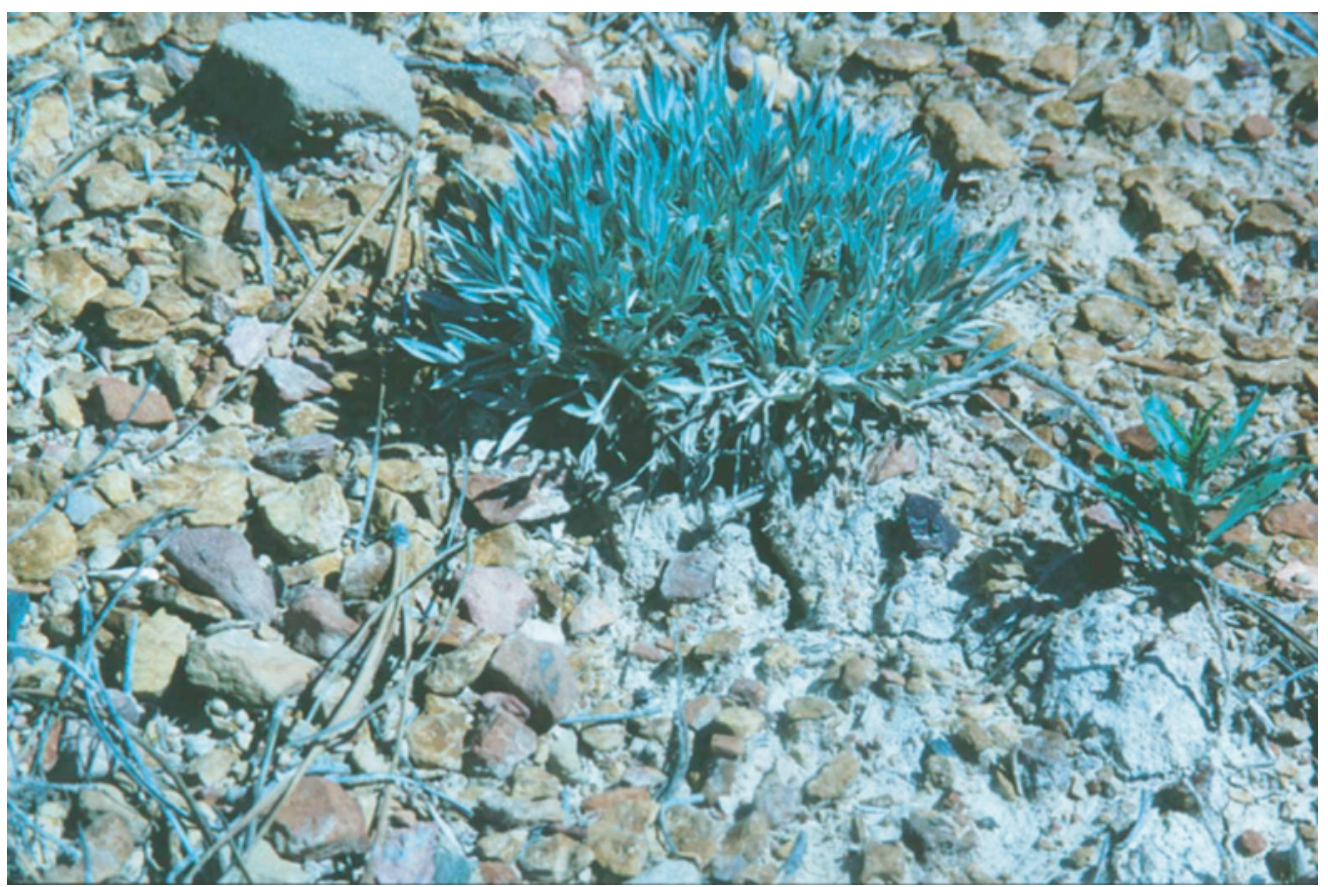

Appendix 3.5. Astragalus gilviflorus (plains milkvetch), a species common in the study area and similar in appearance to A. barrii. Photo taken June 20, 2001. 